\title{
MOLECULAR MIMICRY BETWEEN S PEPLOMER PROTEINS OF CORONAVIRUSES (MHV, BCV, TGEV AND IBV) AND Fc RECEPTOR
}

\author{
Emilia L. Oleszak ${ }^{1}$, Stanley Perlman², Rebecca Parr ${ }^{3}$, Ellen W. \\ Collisson $^{3}$ and Julian L. Leibowitz ${ }^{1}$ \\ ${ }^{1}$ Department of Pathology and Laboratory Medicine, The University of \\ Texas Health Science Center Medical School at Houston, Houston, TX; \\ ${ }^{2}$ Department of Pediatrics, The University of Iowa, Iowa City, IA and \\ ${ }^{3}$ Department of Veterinary Microbiology and Parasitology, College of \\ Veterinary Medicine, Texas A \& M University, College Station, TX
}

\begin{abstract}
In previous studies we have demonstrated molecular mimicry between the $\mathrm{S}$ peplomer protein of Mouse Hepatitis Virus (MHV) and $\mathrm{Fc}_{\gamma}$ Receptor $(\mathrm{Fc} \gamma \mathrm{R})$ of IgG. Rabbit IgG, but not its $\left.\mathrm{F}(\mathrm{ab})_{2}\right)_{2}$ fragments, monoclonal rat and mouse IgG and the rat 2.4G2 anti-mouse $\mathrm{Fc} \gamma \mathrm{R}$ monoclonal antibody $(\mathrm{mab})$ immunoprecipitated natural and recombinant MHV S protein. On the basis of a number of criteria, MHV S peplomer protein exhibits $\mathrm{Fc} \mathrm{IgG}$ binding ability. We report here a molecular mimicry between the $\mathrm{S}$ peplomer protein of Bovine Coronavirus (BCV) and $\mathrm{Fc} \gamma \mathrm{R}$. BCV S peplomer protein which belongs to the same antigenic subgroup as MHV also binds Fc portion of rabbit IgG and is immunoprecipitated by the $2.4 \mathrm{G} 2$ anti-Fc $\gamma \mathrm{R}$ mab. In contrast, Transmissible Gastroenteritis Coronavirus (TGEV) and Infectious Bronchitis Virus (IBV) S peplomer proteins which represent two distinct antigenic subgroups of Coronaviridae do not bind rabbit IgG and do not react with anti-Fc $\gamma \mathrm{R}$ mab. However, homologous swine $\mathrm{IgG}$, but not its $\mathrm{F}\left(\mathrm{ab}^{\prime}\right)_{2}$ fragments, immunoprecipitated from TGEV-infected cells a polypeptide chain with molecular mass of $195 \mathrm{kDa}$, identical to that immunoprecipitated by the T36 mab anti-TGEV S peplomer protein.
\end{abstract}

\section{INTRODUCTION}

We have previously demonstrated molecular mimicry between $\mathrm{S}$ peplomer protein of Mouse Hepatitis Virus (MHV) and $F c_{\gamma}$ Receptor $\left(F c_{\gamma} R\right)$ of $\operatorname{IgG}^{1.3}$. The rat 2.4G2 anti-mouse $\mathrm{F} c \gamma \mathrm{R}$ monoclonal antibody (mab), irrelevant rat and mouse IgGs and rabbit $\mathrm{IgG}$, but not its $\mathrm{F}\left(\mathrm{ab}^{\prime}\right)_{2}$ fragments, immunoprecipitated the $\mathrm{S}$ peplomer protein from cells infected with several strains of MHV, namely JHM, A-59 and MHV-3, but not from uninfected cells. In order to demonstrate that the S protein exhibits $\mathrm{Fc}_{\gamma} \mathrm{R}$ binding ability we have expressed the $\mathrm{S}$ gene using recombinant vaccinia virus. Both irrelevant rabbit $\operatorname{IgG}$, but not its $\mathrm{F}\left(\mathrm{ab}^{\prime}\right)_{2}$ fragments and the $2.4 \mathrm{G} 2$ anti- 
$\mathrm{Fc}_{\gamma} \mathrm{R} \mathrm{mab}^{4}$ immunoprecipitated recombinant MHV-JHM S peplomer protein from cells of murine, rabbit and human origin. These results unequivocally proved that an $\mathrm{Fc}_{\gamma} \mathrm{R}$ binding site resides on MHV S peplomer protein ${ }^{1.3}$. The $\mathrm{Fc} \gamma \mathrm{R}$ binding site is expressed on the cell surface, since MHV-JHM infected cells but not uninfected cells formed rosettes with anti-erythrocyte antibody coated sheep erythrocytes ${ }^{3}$. The 2.4G2 anti-F $\gamma$ R mab inhibits MHV-S mediated fusion "from within" and also neutralizes the virus ${ }^{3}$. Using Dayhoff Align program we have identified two regions of sequence similarity between MHV S peplomer protein and $\mathrm{Fc} \gamma \mathrm{R}$. The purpose of this study is to determine whether there is a molecular mimicry between $\mathrm{Fc}_{\gamma} \mathrm{R}$ and $\mathrm{S}$ peplomer protein of representative viruses of three separate antigenic subgroups within the family of Coronaviridae. We have chosen: (a) Bovine Coronavirus (BCV) as another virus that belongs to the same antigenic subgroups as MHV; (b) Trans-missible Gastroenteritis Virus (TGEV) as the representative of the second subgroup, that includes also Feline Infectious Peritonitis Virus (FIPV) and Human Coronavirus 229 $\mathrm{E}$ (HCV-229E) (c) Infectious Bronchitis Virus (IBV), which is the only member of the third subgroup. Viruses within each subgroups show antigenic crossreactivity but they infect different species and induce different clinical symptoms.

\section{MATERIALS AND METHODS}

Viruses and cells. BCV (MEBUS strain) was provided by Dr. B. Hogue (Baylor College of Medicine, Houston, TX); TGEV was obtained from Dr. C. Bond (Montana State Univ., Bozeman, MT). Tissue culture adapted IBV was provided by Dr. B. Sefton, Salk Inst., San Diego, CA. Bovine HRT-18 cell line, ST cell line and chicken embryo kidney (CEK) cells were previously described ${ }^{5-7}$.

Antibodies. Gnotobiotic calf anti-BCV serum and bovine sera to either Breda virus or Cryptosporidium were obtained from Dr. G. Woode (Texas A \& M Univ.). Mab to TGEV (clone T36) was provided by Dr. Bond. A mouse anti-IBV serum and the 951A5 anti-IBV S peplomer protein mab were developed by R. Parr \& E.Collisson and will be described elsewhere. Purified whole rabbit IgG specific for Micrococcus lysodeicticus (M. lysodeicticus) as well as its $\mathrm{F}\left(\mathrm{ab}^{\prime}\right)_{2}$ fragments were a generous gift of Dr. S.Rodkey (Univ. Texas Medical Sch., Houston). The hybridoma producing the 2.4G2 anti-mouse $\mathrm{Fc} \gamma \mathrm{R}$ mab was purchased from the ATCC (Rockville, MD). Affinity purified goat anti-mouse IgG, goat anti-rat IgG, goat anti-bovine IgG, goat anti-rabbit IgG and affinity purified bovine, swine and chicken $\operatorname{IgG}$ and their $\left.\mathrm{F}(\mathrm{ab})_{2}\right)_{2}$ fragments were purchased from Jackson Immunoresearch Lab. (West Grove, PA).

Metabolic labeling of cells and immunoprecipitation. Confluent ST cells were infected with TGEV at m.o.i. $=5$ and labeled with ${ }^{35} \mathrm{~S}$ Methionine (Met) at $8 \mathrm{hrs}$ post infection (p.i.). Cytoplasmic lysates were prepared $12 \mathrm{hrs}$ p.i. as described'. Confluent CEK cells were infected with tissue culture adapted IBV and labeled with ${ }^{35} \mathrm{~S}$ Met 14 hrs p.i. Cytoplasmic lysates were prepared 15.5 hrs p.i. Confluent HRT-18 cells were infected with BCV at m.o.i. $=1$ and labeled with ${ }^{35} \mathrm{~S}$ Met 9 hrs later. Cytoplasmic lysates were prepared $12 \mathrm{hrs}$ p.i. as described. Control cells were not infected and labeled with ${ }^{35} \mathrm{~S}$ Met as described ${ }^{1}$. Aliquots of $50-70 \mu \mathrm{l}$ (approximately $5 \times 10^{5}$ cells) were immunoprecipitated with appropriate antibodies using Protein-A Sepharose beads (Pharmacia) and the immune complexes were analyzed by SDS-PAGE ${ }^{12}$.

\section{RESULTS}

Molecular mimicry of BCV S glycoprotein and $\mathbf{F c} \gamma \mathbf{R}$. There is remarkable sequence homology between S peplomer proteins of MHV-JHM and BCV.To examine 


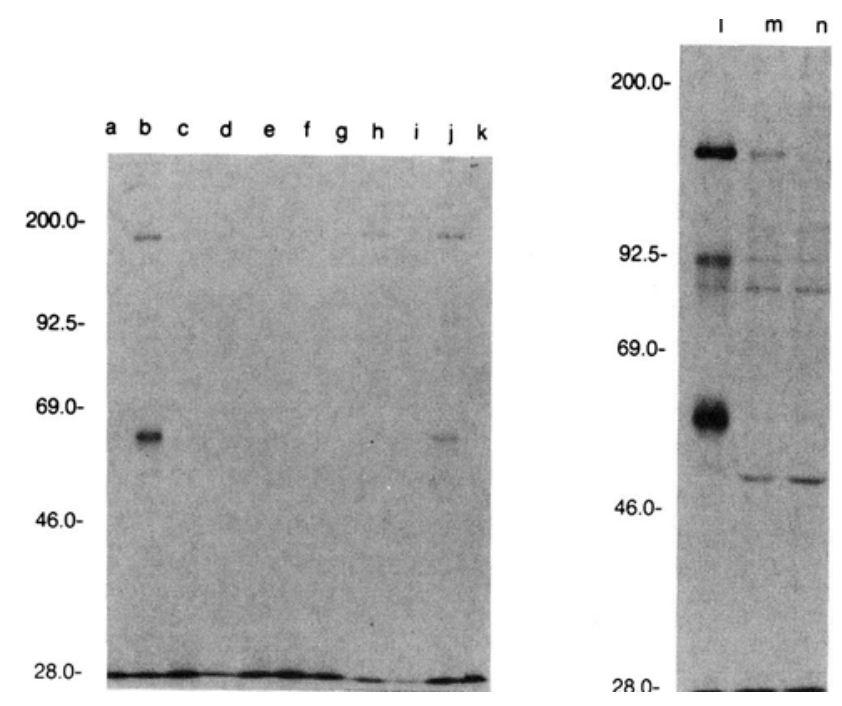

Figure 1. Immunoprecipitation of BCV-S peplomer protein by purified rabbit IgG: Lysates were prepared from ${ }^{35} \mathrm{~S}$ Met labeled BCV- or mock-infected cells. BCVinfected lysates were immunoprecipitated with goat anti-bovine IgG (lane a); gnotobiotic bovine anti-BCV (lane $b$ and l); bovine anti-Breda virus anti-bodies (lane c); bovine anti-Cryptosporidium antibodies (land d); $2.4 \mathrm{G} 2$ anti-Fc $\gamma \mathrm{R}$ mab (lane $\mathrm{h}$ ); goat anti-rat IgG (lane i); goat anti-MHV S serum (lane j);purified rabbit IgG (100 $\mu$ g, specific for M. lysodeicticus) (lane $\mathrm{m}$ ). Mock-infected lysates were immunoprecipitated with specific polyclonal antibodies to BCV (lane e); bovine anti-Breda virus (lane f); bovine anti-Cryptosporidium (lane g) and purified rabbit $\operatorname{IgG}(100 \mu \mathrm{g}$, specific for M. lysodeicticus)(lane $\mathrm{n}$ ). The immunoprecipitates were analyzed by SDS-PAGE ${ }^{1,2}$.

whether BCV S peplomer protein exhibits the ability to bind the Fc portion of IgG, we immunoprecipitated BCV-infected cell lysates with either the $2.4 \mathrm{G} 2$ anti-F $\gamma \mathrm{R}$ mab or purified rabbit IgG or its $\mathrm{F}\left(\mathrm{ab}^{\prime}\right)_{2}$ fragments and analysed the immune complexes by SDS-PAGE (Fig. 1). Both the 2.4G2 anti-Fc $\gamma \mathrm{R}$ mab and the purified rabbit IgG, but not its $\mathrm{F}(\mathrm{ab})_{2}$, fragments, immunoprecipitated a polypeptide chain with molecular mass of $190 \mathrm{kDa}$, identical to that of the BCV S peplomer protein, which was immunoprecipitated by specific bovine serum to BCV. This anti-BCV specific serum also immunoprecipitated the BCV nucleocapsid protein $(52 \mathrm{kDa})(\mathrm{Fig}$. 1 ). The same two proteins were immunoprecipitated by polyclonal anti-serum specific for MHV. In addition, the same two proteins of 190 and $52 \mathrm{kDa}$ were immunoprecipitated by "irrelevent" commercially available affinity purified bovine IgG, suggesting that these commercially available preparations of bovine $\operatorname{IgG}$ were from animals exposed to the virus (data not shown). This is not unexpected in view of the high incidence of BCV infection ${ }^{8,9}$. Gnotobiotic homologous control antibodies specific for Breda virus or specific for Cryptosporidium, used at concentrations significantly lower than that of the affinity purified bovine IgG, as well as secondary antibodies, did not immunoprecipitate any protein from BCV-infected cells or control cells (Fig. 1). All these results suggest that BCV S peplomer protein also binds the $\mathrm{Fc}$ region of IgG.

Reactivity of TGEV and IBV S peplomer proteins with Fc IgG. BCV, TGEV and IBV belong to three distinct antigenic subgroups of Coronaviridae ${ }^{10}$. We examined the ability of TGEV and IBV S peplomer proteins to bind rabbit IgG and to react with the $2.4 \mathrm{G} 2$ anti-Fc $\gamma \mathrm{R}$ mab (Fig. 2 and 3, respectively). Neither purified rabbit IgG 


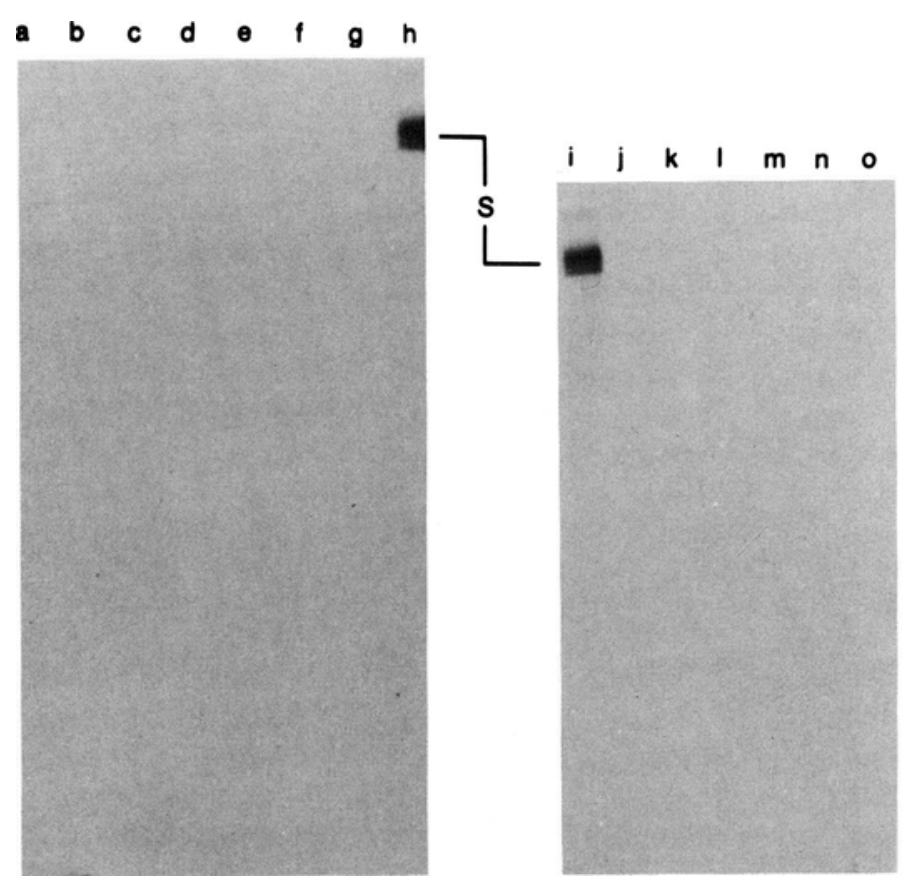

Figure 2. Immunoprecipitation of TGEV-S peplomer protein: Lysates from ${ }^{35} \mathrm{~S}$ Met labeled TGEV-infected cells were immunoprecipitated with goat anti-rat IgG (lane c); $2.4 \mathrm{G} 2$ anti-Fc $\gamma \mathrm{R}$ mab (lane d); goat anti-mouse IgG (lane f); mouse anti-TGEV $\mathrm{S}$ peplomer protein T36 mab (lane h \& i); goat anti-rabbit IgG (lane k); purified rabbit IgG (lane $\mathrm{m}$ ); F(ab') ${ }_{2}$ of rabbit IgG (lane n); goat anti-MHV-JHM (lane o) and analyzed by SDS-PAGE ${ }^{1,2}$. Mock-infected lysates were immunoprecipitated with goat anti-rat IgG (lane a); goat anti-mouse IgG (lane e); T36 mab (lane g); goat antirabbit IgG (lane j); purified rabbit IgG (lane l) and analyzed by SDS-PAGE ${ }^{1,2}$.

nor the $2.4 \mathrm{G} 2$ anti-Fc $\gamma \mathrm{R}$ mab immunoprecipitated any proteins from TGEV-infected cells. The T36 mab specific for TGEV S peplomer protein immunoprecipitated a 195 $\mathrm{kDa}$ protein from TGEV-infected cells (Fig. 2; lane $\mathrm{h}$ and i), but not from control, uninfected cells (Fig. 2, lane g). Secondary antibodies did not immunoprecipitate any proteins from TGEV-infected or control uninfected cells. Anti-MHV S protein antibody did not immunoprecipitate TGEV S protein (Fig. 2, lane o), in agreement with the fact that TGEV belongs to a distinct antigenic group than MHV and BCV. However, homologous swine $\mathrm{IgG}(50 \mu \mathrm{g})$, but not its $\mathrm{F}\left(\mathrm{ab}^{\prime}\right)_{2}$ fragments, immunoprecipitated from TGEV-infected cells a protein of $195 \mathrm{kDa}$, identical to that immunoprecipitated by the T36 mab anti-TGEV S peplomer protein (data not shown). This homologous swine IgG did not immunoprecipitate any other TGEV proteins, in agreement with the findings that the prevalence of anti-TGEV antibodies is low in these animals ${ }^{11}$.

Polyclonal antibodies to IBV, the only member of the third antigenic subgroup of Coronaviridae, immunoprecipitated several structural IBV proteins: S peplomer protein $(180 \mathrm{kDa})$ nucleocapsid $(51 \mathrm{kDa})$ and matrix protein ( Fig. 3, lane d). S peplomer protein was also immunoprecipitated by the 951A5 anti-IBV mab. None of these anti-bodies immunoprecipitated any polypeptide chains from control uninfected cells. The $2.4 \mathrm{G} 2$ anti-F $\gamma \mathrm{R}$ mab or purified rabbit IgG did not immunoprecipitate any protein from IBV-infected cells (Fig. 3, lane h and f). We have also carried out studies using "irrelevant" commercially available purified chicken IgG. Homologous, chicken IgG immunoprecipitated several stuctural IBV proteins including S peplomer protein, 


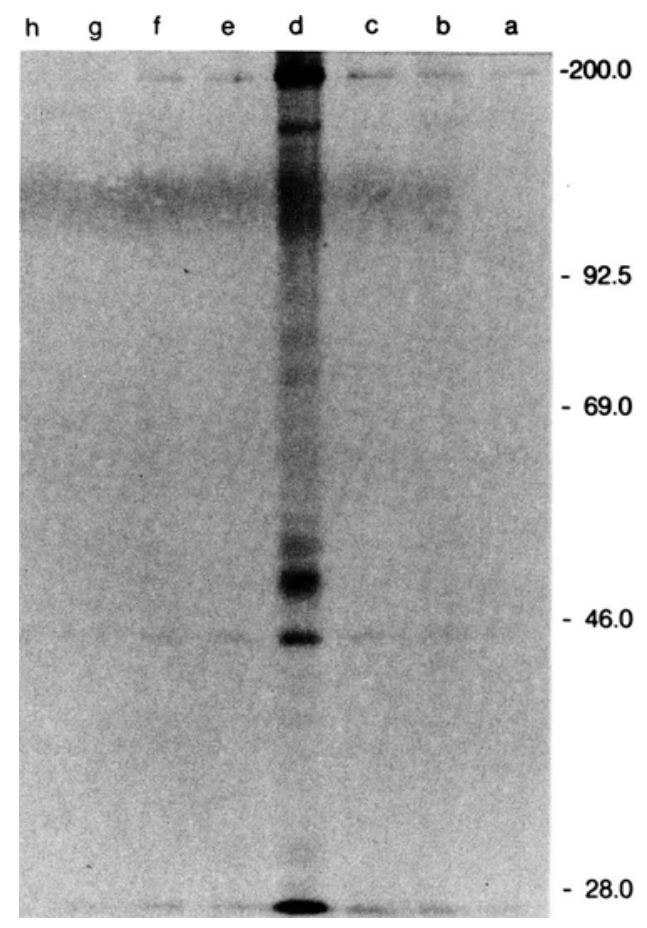

Figure 3. Immunoprecipitation analysis of IBV S peplomer protein: ${ }^{35}$ S Met labeled IBV infected cell lysates were immunoprecipitated with the 951A5 mab specific for IBV peplomer protein (lane b); mouse polyclonal antibodies specific for IBV (lane d); purified rabbit IgG (lane f); $\mathrm{F}\left(\mathrm{ab}^{\prime}\right)_{2}$ fragments of rabbit IgG (lane g); the 2.4G2 anti-Fc $\gamma \mathrm{R}$ mab (lane $\mathrm{h}$ ). Mock-infected cell lysates were immunoprecipitated with 951A5 mab (lane a); mouse anti-IBV antibodies (lane c); and purified rabbit IgG (lane e). The immunoprecipitates were analyzed by SDS-PAGE ${ }^{1,2}$.

nucleocapsid and matrix proteins (data not shown). In view of the high incidence of IBV infection ${ }^{12}$, this is not surprising and suggests that these commercially available IgG preparations were from chicken exposed to IBV. Experiments using truly "irrelevant" chicken IgG (without anti-IBV contaminating antibodies) are needed to determine whether IBV S peplomer protein binds homologous IgG and are being carried out.

\section{DISCUSSION}

We have previously shown molecular mimicry between $\mathrm{S}$ peplomer protein of $\mathrm{MHV}$ and $\mathrm{Fc} \gamma \mathrm{R}^{1-3}$. Using Dayhoff Align Program and Monte Carlo Analysis we have identified two regions of sequence similarity between S peplomer protein (of MHV$\mathrm{JHM}$ or A-59) and mouse $\mathrm{Fc} \gamma \mathrm{R}$ (Domains \#1 \& \#2)1. These two regions of sequence similarity are located within the $\mathrm{N}$-terminal subunit (S1) of the $\mathrm{S}$ peplomer protein. In this report, we have examined the binding of immunoglobulin to $S$ peplomer proteins of several coronaviruses representing three distinct antigenic subgroups of Coronaviridae. The $2.4 \mathrm{G} 2$ anti-F $\gamma \mathrm{R}$ mab and purified rabbit $\mathrm{IgG}$ were employed as two representative $F c_{\gamma} R$ recognizing reagents. Both immunoprecipitated BCV S peplomer protein, but not S peplomer proteins of TGEV or IBV (Fig. 2 and 3). $\mathrm{F}(\mathrm{ab})_{2}$ fragments of rabbit IgG did not immunoprecipitate BCV S peplomer protein. Therefore, there is molecular mimicry between BCV S peplomer protein and $\mathrm{Fc} \gamma \mathrm{R}$. 
BCV and MHV belong to the same antigenic subgroup and show remarkable sequence homology ${ }^{13}$. Direct comparison of the amino acid sequence of the S1 subunits of JHM and BCV showed $62 \%$ identity. The S1 subunits of A-59 and BCV showed $60 \%$ identity. Also, there are high levels of homology in the S2 subunits of JHM, A-59 and BCV $(75 \%$ \& $74 \%$ respectively). It has been previously demonstrated, that the S peplomer protein of $\mathrm{MHV}$ and $\mathrm{BCV}$ antigenically crossreact ${ }^{14}$. We report here another common property of S peplomer proteins of these two viruses: both are able to bind the Fc portion of rabbit IgG and both are immunoprecipitated by the $2.4 \mathrm{G} 2$ anti$\mathrm{Fc} \gamma \mathrm{R}$ mab. The region of sequence similarity between MHV $\mathrm{S}$ peplomer protein (Domain \#1) and $\mathrm{F} \gamma \gamma \mathrm{R}$ is conserved in BCV S peplomer protein, which is in agreement with our findings that both peplomer proteins have an $\mathrm{Fc}$ binding site. However, it remains to be established whether this domain \#1 contain the Fc binding epitope.

TGEV and IBV represent two distinct antigenic subgroups of Coronavirida ${ }^{10}$. Computer analysis of the sequences of the structural proteins of MHV, TGEV and IBV did not reveal any homologies ${ }^{15}$. Bovine, swine and chicken $F c$ receptors have not been sequenced and therefore their sequences can not be compared to those of the corresponding S peplomer proteins.

The results that purified rabbit IgG or the $2.4 \mathrm{G} 2$ anti-Fc $\gamma \mathrm{R}$ mab did not immunoprecipitate any polypeptide chains from TGEV- or IBV-infected cells do not imply that there is no molecular mimicry between the TGEV and IBV peplomer proteins and the $F c_{\gamma} R$. To the contrary, homologous swine IgG, but not its $F(a b)_{2}$ fragments, immunoprecipitated from TGEV-infected cells the TGEV S peplomer protein (data not shown). This homologous swine IgG did not contain anti-TGEV antibodies and did not immunoprecipitate any other TGEV proteins, in agreement with the findings that the prevalence of anti-TGEV antibodies is low in swine ${ }^{11}$. Studies to determine whether "irrelevant" bovine IgG or chicken IgG immunoprecipitated the S peplomer proteins from BCV- or IBV-infected cells, respectively, were hindered by the fact that the "irrelevant", homologous IgG preparation available to us were very likely contaminated with anti-viral antibodies, because they immunoprecipitated several structural viral proteins. Immunoprecipitations experiments using bovine and chicken IgG preparations that do not contain anti-viral antibodies are needed and are being carried out.

\section{REFERENCES}

1. Oleszak E. and Leibowitz J. Virology 176:70(1990).

2. Oleszak E., Perlman S. and Leibowitz J. Virology 186:122(1992).

3. Oleszak E. and Leibowitz J. Adv. Exper. Biol. Med. 276:51(1991).

4. Unkeless J.C. J. Exp. Med. 150:580(1979).

5. Lapps W., Hogue B.G. and Brian D.A. Virology 157:47(1987).

6. Collisson E.W., Li J.Z., Sneed L.W., Peters M.L. and Wang L. Vet. Microbiol. 24: 261(1990).

7. Choi C.S., Murtaugh M.P. and Molitor T.W. Arch. Virol. 115:227(1990).

8. Alenius S., Niskanen R., Juntti N. and Larsson B. Acta Vet. Scand. 32:163(1991).

9. Heckert R.A., Saif L.J., Myers G.W. and Agnes A.G. Am. J. Vet. Res. 52:845(1991).

10. Siddell S., Wege H. and Ter Meulen V. J. Gen. Virol. 64:761(1983).

11. Brown I.H. and Paton D.J. Vet. Rec. 128:500(1991).

12. Gelb J. Jr., Leary J.H. and Rosenberger J.K. Avian Dis. 27:667(1983).

13. Hogue B., King B. and Brian D. J. Virol. 51:384(1984).

14. Boireau P., Cruciere C. and Laporte J. J. Gen. Virol. 71:487(1990).

15. Jacobs L., deGroot R., van der Zeijst B.A.M., Horzinek M. and Spaan W. Virus Res. 8:363(1987). 